International Journal of Current Advanced Research

ISSN: O: 2319-6475, ISSN: P: 2319 - 6505, Impact Factor: SJIF: 5.995

Available Online at www.journalijcar.org

Volume 6; Issue 4; April 2017; Page No. 3355-3356

DOI: http://dx.doi.org/10.24327/ijcar.2017.3356.0271

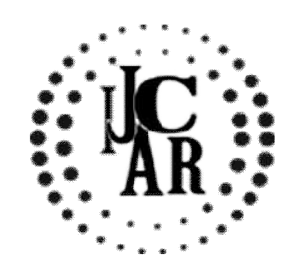

Review Article

\title{
BISPHENOL A ABSENT AND HYDROPHILIC PIT AND FISSURE RESINS- A REVIEW
}

\author{
Deepti Anna John* and Shanmugaavel.A.K
}

Department of Pedodontics, Saveetha Dental College, Saveetha University Chennai, Tamil Nadu

\begin{tabular}{ll}
\hline A R T I C L E I N F O & A B S T R A C T \\
\cline { 1 - 2 } Article History: & $\begin{array}{l}\text { Dental caries is one of the most common oral diseases seen in children and Pit and fissure } \\
\text { sealants are used as a prophylactic measure to prevent these caries in the pit and fissure } \\
\text { surfaces of the posterior teeth. }\end{array}$ \\
$\begin{array}{l}\text { Received } 8^{\text {th }} \text { January, } 2017 \\
\text { Received in revised form } 10^{\text {th }} \text { February, } 2017\end{array}$ & $\begin{array}{l}\text { The pit and fissure sealants are mainly composed of Bisphenol A or BPA based epoxy } \\
\text { resins which have an oestrogen like releasing affect and are hydrophobic in nature which } \\
\text { Accepted } 22^{\text {nd }} \text { March, } 2017\end{array}$ \\
$\begin{array}{l}\text { requires adequate isolation and moisture control to have the desired effect. } \\
\text { Published online } 28^{\text {th }} \text { April, } 2017\end{array}$ & $\begin{array}{l}\text { Therefore, recent advances in pit and fissure sealants have been made to reduce and } \\
\text { eliminate the unwanted effects. The aim of the review is to study the effects and properties } \\
\text { of two newly introduced pit and fissure sealants that are the non-Bisphenol A containing pit } \\
\text { Key words: }\end{array}$ \\
and fissure sealants and Hydrophilic pit and fissure sealants.
\end{tabular}

Copyright $₫ 2017$ Deepti Anna John and Shanmugaavel.A.K. This is an open access article distributed under the Creative Commons Attribution

License, which permits unrestricted use, distribution, and reproduction in any medium, provided the original work is properly cited.

\section{INTRODUCTION}

A sealant is a plastic like material that is clear or opaque which is placed on the pit and fissure surfaces of the teeth where dental caries most commonly occurs. The sealant acts as a barrier to occlude and protect the pit and fissure surfaces from food and bacteria, as the sealant removes the deeper anatomy and ensures better oral hygiene since the tooth is easier to clean. Sealants have been used in clinical practice for many decades, so over the past few years sealants have gone through many changes in their structure and usage for better and easier application.

The first-generation sealants were liquid resins placed on the tooth surface and underwent polymerization with ultraviolet light. These sealants were replaced with sealants that polymerize by a more safer and efficient source of light and chemically cured materials. Sealants are now classified according to the method of polymerization: autopolymerisation which makes up the second-generation sealants and photopolymerization which are referred to as third-generation sealants [1]. The fourth generation sealants consist of fluoride releasing property that gives a better protection of the tooth against caries.

Traditionally, the pit and fissure sealants are hydrophobic in nature, therefore it cannot be applied on a moist surface to ensure success. Therefore for doing the procedure isolation is essential but act as a hindrance in the case of erupting teeth.

*Corresponding author: Deepti Anna John

Department of Pedodontics, Saveetha Dental College,

Saveetha University Chennai, Tamil Nadu
The idea of incorporating hydrophilic components in the sealants was proposed, however the addition of the new materials would increase the cost, time and make the procedure technique sensitive. In recent years, more studies have be done to make a moisture tolerant resin material which will serve well in a moist oral cavity [2].

The sealants are mainly composed of BIS-GMA, an acronym for a reaction product of bisphenol A (BPA) and Glycidyl methacrylate. This BPA belongs to a group of chemicals called xenoestrogens that have a potential of binding with the oestrogen receptors that leads to biologicals effects likeoestrogen.This has caused some concern among the practitioners and patients, hence sealants without the BPA component are being studied [3]. The purpose of the article is to learn and gain a better overview about the latest advancements in Pit and fissure sealant technology that are hydrophilic and Bisphenol absent A sealants.

\section{DISCUSSION}

The pit and fissure sealants are an important method to prevent pit and fissure caries, by forming a seal that helps by blocking the entry of nutrients to the bacteria that is present in the dental caries. These surfaces are more vulnerable than any other surfaces of the tooth, hence the use of the sealant is an important step in caries prevention [4].

Commercially hydrophobic based resin sealants are available, which is highly technique sensitive and the success depends on factors such as patient co-operation, operator variability and contamination of the operating field. But the most difficult aspect of these sealants is the need of highly moisture free field making it difficult to place on erupting molars [5]. 
A study was conducted to compare and evaluate hydrophobic and hydrophilic pit and fissure sealants where the two groups of children used hydrophobic and hydrophilic fissure sealants and it was concluded that the second group of sealants provided better results and was highly recommended to be used in children who were very young, high risk of caries, excessive salivation, mentally challenged and disabled, uncooperative and community care programs [2].

Embrace WetBond is one of the few hydrophilic sealants in the market with features such as Self-adhesive, self-priming and less technique sensitive with Resin Activated Integrated Network[R.A.I.N], improved hydrophilic technology, margin free and hydro-balanced, continuous fluoride release, Water activated and $\mathrm{pH}$ controlled, Water miscible and protects tooth from micro leakage. The bonding is done by both chemical and micro-mechanical in nature. It is also bisphenol A free (BPA)[6,7]. Bisphenol A (BPA) is a chemical most commonly found in polycarbonate plastics and resins. It is one of the endocrine disrupting chemicals and that has caused some concern regarding exposure to BPA and its effects on the human body. Laboratory studies also indicated gene mutation as a potential effect with exposure.BPA stimulates cell proliferation and induces multiplication of oestrogen like cells that initiate mammary gland and uterine differentiation [8].

Although studies have proven that most dental materials do not release BPA except few resins such as the Pit and fissure sealants. But the amount that is released is about $0.05 \mathrm{mg} / \mathrm{kg}$ bw/day which by ADA has been reported as safe levels [9]. Evidence shows that BPA released from resins does not pose any threat. But because of the toxic effects of BPA it is recommended that the release of this chemical from resins be prevented. Research is still being continued so study if even the low levels of BPA could pose a threat and cause oestrogenic effects as time progresses. Embrace WetBond sealants prove to be also one of the few sealants that are not composed of Bis-GMA, hence being a one of a kind sealant.

\section{CONCLUSION}

Hydrophilic and Bisphenol Absent sealants have proven to make pit and fissure sealant application safer and more easier for placement and also helps to prevent the unwanted effects of hazardous chemical that could cause any effect in the patient.

\section{References}

1. William F. V, F.Thomas McIver.Pit and Fissure sealants- An Overview of Issues Related to Diagnosis and Treatment Decisions.

2. A.Ratnadithya,M.G.MKumar,S.S.AJogendra et alClinical Evaluation of Retention in Hydrophobic and Hydrophillic Pit and Fissure Sealants- A two year follow up study.Jul-Sep 2015,Vol 7,Is 3,171-179

3. A.Azarpahooh, P.A Main- Is There a Risk of Harm or Toxicity in the Placement of Pit and Fissure Sealant Materials? A Systematic Review. JCDA, Mar 2008, Vol 74,No2,pg 179-183

4. Joseph O Donnell P. In vivo evaluation of Embrace TMWetbondTM Pit And Fissure Sealant ; Internal Report 2003.www.linkedin.com/ pub/joseph-odonnell/18/7A6/449

5. Ana Karina Mascarenhas, Huda Nazar, Sabiha AlMutawaa, Pramod soparkar effectiveness of primer and bond in sealant retention and caries prevention. Pediatric Dentistry 2008; 30(1): 25-8.

6. Subramanium P, Konde S, Mandanna DK. Retention of a Resin Based Sealant and a Glass Ionomer used as a Fissure Sealant - A comparative clinical study. J Indian Socpedod Prevent Dent. 2008; 14(3): 119-24.

7. Jane AW. Pit and fissure sealants in High-Caries-Risk Individuals. Journal of Dental Education 2001; 65(10): 1084-90.

8. Ben-Jonathan N, Steinmetz R. Xenoestrogens: The emerging story of bisphenol A. TEM, 1998; 9: 124128.

9. Source: http://www.ada.org/2989.aspx? currentTab=1 .

\section{How to cite this article:}

Deepti Anna John and Shanmugaavel.A.K (2017) ' Bisphenol A Absent And Hydrophilic Pit And Fissure Resins- A Review', International Journal of Current Advanced Research, 06(04), pp. 3355-3356.

DOI: http://dx.doi.org/10.24327/ijcar.2017.3356.0271 